are seen in many countries. It seems, too, that whatever China is doing, there is a Western thought leader whom Williams indicates must be an influence. This is fatiguing. It is not difficult to find as many arguments in China claiming that most of today's progressive environmental ideas are rooted in ancient Chinese philosophy.

At one point, Williams misinterprets the technical and cultural practices in Chinese calligraphy and poetry to make the shaky assertion that China has no concept of copyright. Further, he claims that China has been "nicking ideas from the West to fuel its own awakening" for the past four decades, although he adds that this is "no bad thing". By contrast, he depicts Western nations as authentic, confident and with "a generally accepted narrative about their own societies over time".

If Williams's criticisms are based on innocent misinterpretation, there are two likely reasons alongside the dizzying pace of change. First, the fine print around China's eco-cities can be lost in translation. The country's accrediting team clearly states that it includes cities, towns, districts and development zones, often all translated as eco-cities. Second, demonstration projects are common, to allow others to learn from front runners. Thus, eco-cities are more about recognizing process and effort than the end stage.

Williams concludes with a discussion of China's efforts in renewable-energy development, innovation and other relevant areas, and lists the country's top eco-cities - which are mentioned rarely, if at all, in earlier chapters. He even warns against Western bias when interpreting Chinese issues. I was left wondering whether the book's shifts in tone and perspective were the result of Williams's views evolving.

China's Urban Revolution is ultimately - as a collection of "contradictory viewpoints" - unsatisfying. But many of the facts presented are fascinating.

Xuemei Bai is an adjunct professor at Beijing Normal University, and a professor in the urban environment and human ecology at the Australian National University in Canberra.

e-mail:xuemei.bai@anu.edu.au

\title{
ORNITHOLOGY
}

All eyes on the
10,000 species

Stuart Pimm considers the obsessive, sometimes dark side to the joyous pursuit of watching birds.

$\mathrm{W}$ hen the ship Victoria, the last remnant of Ferdinand Magellan's round-the-world voyage, returned to Seville in 1522, just 18 men survived from an expedition crew of more than 200. Magellan was not among them. Victoria held a fortune in spices - and the feathers of birds of paradise. The specimens' feet and wings had been removed, so people thought that the birds moved by divine means. Their shimmering plumage inspired wonder that galvanized both ornithologists and hunters.

Magellan's voyage, recounted in Bernd Brunner's Birdmania, is one manifestation among multitudes of humanity's great obsession with birds. By the end of 2016, one-third of a million people had contributed more than one-third of a billion observations to eBird (http://ebird.org), the world's largest citizenscience project. We know the natural history and distribution of birds much better than those of any other group. And colourful people walk the paths to this knowledge, as is amply shown in both Birdmania and Noah Strycker's Birding Without Borders. On a hike in Colombia, I contemplated these books - and concluded that I must write about passions for birds that have dark, even fatal, undercurrents.

In Brunner's tour of bird devotees through history, we meet a cast including thirteenth-century Holy Roman Emperor Friedrich II von Hohenstaufen, who authored a treatise on falconry, and twentieth-century US ornithologist Robert Porter Allen, who did much to protect the whooping crane (Grus americana). Brunner reveals how hummingbirds were admired by European travellers long before becoming a highlight of Victorian specimen cabinets. Although most species of these acrobatic wonders live in the remote Andes and Amazon, the drive to find new ones was intense. Only 34 were known by 1788 , but by 1900 , taxonomists had described 312 of the current 336. Avid collector John Gould recorded most of them in his lavishly illustrated Monograph of the Trochilidae, or Family of Hummingbirds (1849-61). The ranges of some hummingbirds are still being uncovered.

The end of this golden age of discovery was marked by a controversial figure: Richard Meinertzhagen, chair of the British Ornithologists' Club. A career army officer, he participated in military exploits such as Edmund Allenby's 1917 victory in the Middle East. He was also an explorer, touring Afghanistan in 1937 with a young Salim Ali, destined to become India's most distinguished ornithologist. There, Meinertzhagen described a new species of snowfinch (Montifringilla

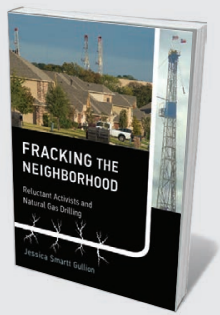

Fracking the Neighborhood: Reluctant Activists and Natural Gas Drilling Jessica Smartt Gullion (MIT Press, 2017) North Texas takes centre stage in sociologist Jessica Smartt Gullion's study of urban US fracking. She explores the state's drilling culture and industrial health risks, and interviews locals forced to cope with fracking on their doorstep.

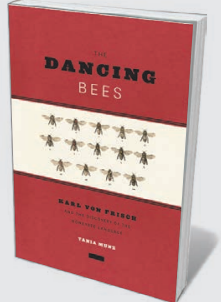

The Dancing Bees

Tania Munz (Univ. Chicago Press, 2017) In this compelling account of the work of Karl von Frisch, Tania Munz shows how, despite pressures from the Nazis, he advanced studies of animal communication. Notably, he discovered how bees 'waggle dance' to indicate food sources (see Mark L. Winston's review: Nature 533, 32-33; 2016). 


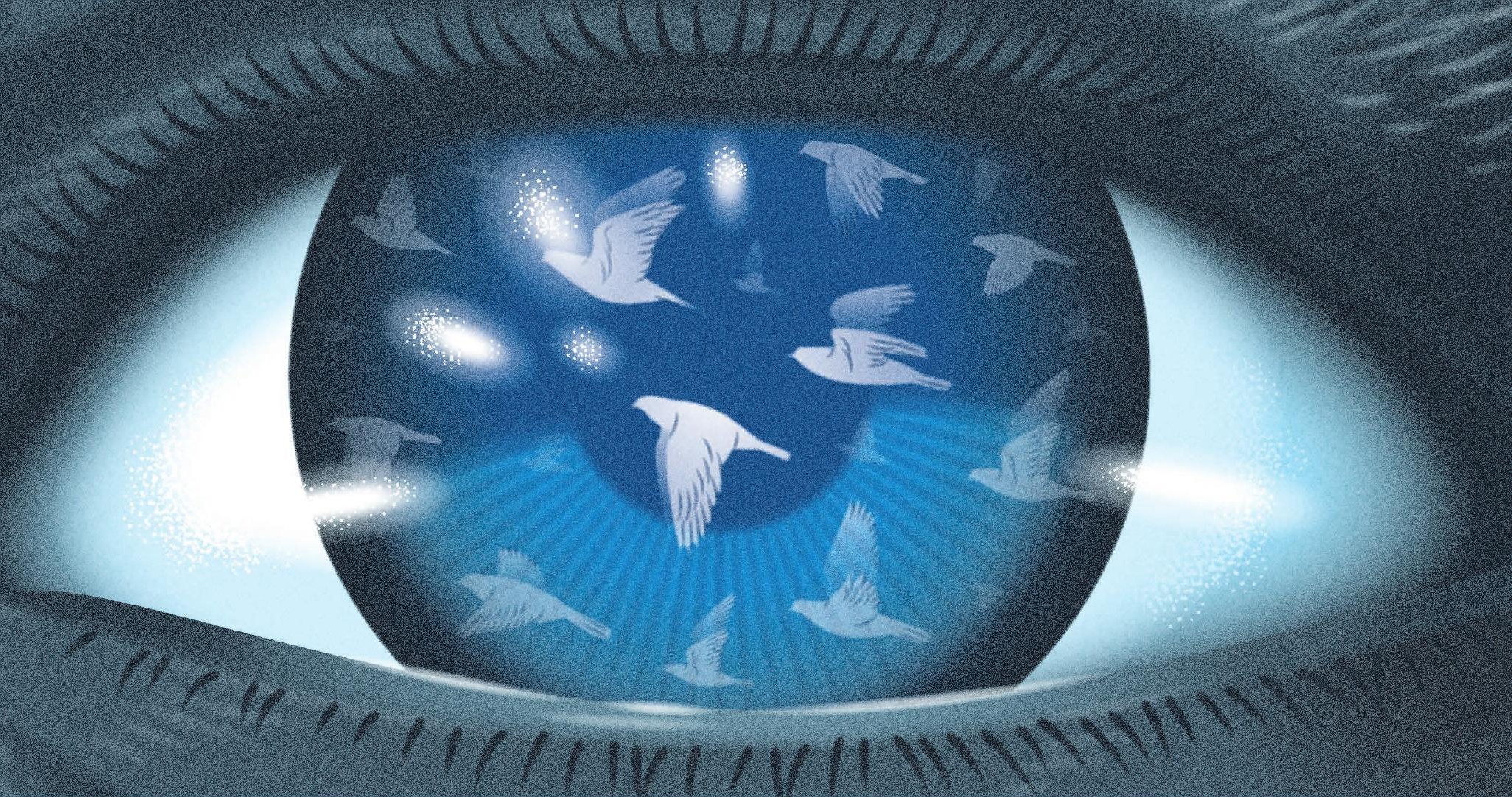

theresae), the existence of which I can confirm: mentored by Salim Ali, I ringed some on an expedition in 1970. But Meinertzhagen was a monumental fraud. He stole specimens, mislabelled them and added false locations. As Brunner relates, Meinertzhagen's wife, ornithologist Ann Jackson, died in suspicious circumstances.

In Birding without Borders, Strycker records his quest to see as many species as possible in a year: what's known as a "big year". That comes with bragging rights, but demands money and time. Some of the more than 10,000 known bird species have large geographical ranges, so there are many places to see them. Yet 5,000 have ranges smaller than the median of 280,000 square kilometres. Fortunately, these are geographically concentrated (see www.biodiversitymapping.org). So a big year is mostly a matter of traversing the tropics: Central America, the northern Andes, coastal Brazil, West Africa, the East African mountains, Madagascar, northeast India, the islands of southeast Asia, New Guinea and Queensland, Australia. Strycker also visits other places, often lamenting that he doesn't see enough species to keep up his total.

His epic mission is made possible by a
Birdmania: A Remarkable Passion for Birds BERND BRUNNER (TRANSLATED BY JANE

BILLINGHURST)

Greystone: 2017.

Birding Without Borders: An Obsession, a Quest, and the Biggest Year in the World NOAH STRYCKER

Houghton Mifflin Harcourt: 2017

global network of guides. They drive him to forests and play tapes of the bird's song. Hopefully the bird responds or, better, pops out to see what's going on. Hummingbirds are lured to sugar-water feeders. My favourite, the small, upright antpittas, feed mainly on forest floors; they are hard to see, but some have been trained to emerge and feed on worms.

Strycker finds 6,042 species, beating the previous record - and does so travelling with a very restricted wardrobe. (When I asked one of his Colombian guides what he thought of Strycker, he answered, "Smelly.") In my view, however, visiting well-trodden paths with the same guides, and playing the same recordings to lure the same birds, may harm individual birds. And it does not contribute anything new to our knowledge of their distributions. I cherish half a century of birding solitude with binoculars, a notebook and, in places such as Afghanistan, not even a bird book.

Colombia tops the global league with most bird species, and most species seen in one day. Its growing birding community penetrates remote areas and pieces together which species aren't being seen. That provides invaluable data for conservation. And along the dirt track to Buenaventura, in a cloud-forest shack perched precariously on an Andean hillside, works Doña Dora. She serves bananas and papayas to a dozen species of brightly coloured tanagers, and massive lunches of soup and empanadas to birders. Here, and in a thousand similar places worldwide, the bright side of bird watching is providing income to poor, rural communities and incentives to protect remaining ecosystems.

Stuart Pimm is professor of conservation at the Nicholas School of the Environment at Duke University in Durham, North Carolina. He directs the non-profit SavingSpecies, www.savingspecies.org, and tweets@StuartPimm.

e-mail:stuartpimm@me.com

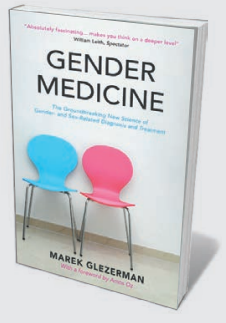

\section{Gender Medicine}

Marek Glezerman (Duckworth Overlook, 2017)

Gender disparities in medicine are rife: less than $30 \%$ of participants in cardiovascular-disease trials are female, for instance. Medic Marek Glezerman advocates gender-specific therapy that factors in issues such as the menstrual cycle altering the efficacy of some pain-relief medication.

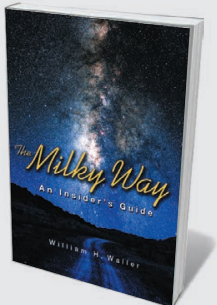

The Milky Way: An Insider's Guide William H. Waller (Princeton Univ. Press, 2017) Spanning star formation and Italian polymath Galileo Galilei's handmade spyglasses, astronomer William Waller's sweeping chronicle examines the formation of the Milky Way and the history of mapping and researching the 13-billion-year-old Galaxy. 